\title{
Simplification of Lipase Design in the Enzymatic Kinetic Resolution of Amines by Saturation Transfer Difference NMR
}

\author{
Marcio S. Silva* and Daniel Pietrobom \\ Centro de Ciências Naturais e Humanas (CCNH), Universidade Federal do ABC (UFABC), \\ Av. dos Estados, No. 5001, 09210-180 Santo André-SP, Brazil
}

\begin{abstract}
In this work, we demonstrate a nuclear magnetic resonance (NMR) method for racemic amide and lipase interaction as a first-pass design method in the enzymatic kinetic resolution of amines. As a novel adaptation of commonly used protein-ligand screening NMR methodologies, this approach relies upon a lipase-amide interaction wherein the time-consuming is reduced drastically and new insights are produced during the development of biocatalysis reactions.
\end{abstract}

Keywords: STD NMR, biocatalysis, enzymatic kinetic resolution, amines

\section{Introduction}

Nowadays, the development of new methods for preparing chiral organic compounds is a major goal of synthetic organic chemists ${ }^{1}$ due recognized importance of chirality in biological processes by differences in affinity that each enantiomer presents for receptors and/ or enzymes. ${ }^{2}$ Biocatalysis, that consists in the use of enzymes as catalysts, is one of the most efficient routes to enantiopure compounds. ${ }^{3}$ The growth of biocatalysis is because of the production and discovery of new enzymes and applications in a wide variety of chemical reactions. ${ }^{4}$

The design and optimization of biocatalytic reactions are based on the same rules as traditional organic reactions, such as temperature, $\mathrm{pH}$, substrate and other features. However, the insights about how these parameters affect the performance of enzymatic reaction are a harder task. These difficulties are inserted into any field in which employs biological systems. Furthermore, the evaluation of enzymes that catalyze new organic reactions is a complex activity and time consuming, requiring a tedious labor intensive process that is generally referred as an enantiomeric excess (ee), turnover number (TON), yield (\%), time (hours or days) and experimental conditions.

The enzymatic reaction requires an interaction of active site of the enzyme to the substrate. In this context, nuclear magnetic resonance (NMR) has become a powerful technique to advance studies of enzyme-substrate (proteinligand) interactions. ${ }^{5}$ Numerous NMR techniques have been

*e-mail: s.marcio@ufabc.edu.br used for characterizing these complexes. One technique that has exhibited promise for rapid screening, the saturation transfer difference (STD), utilizes cross relaxation. ${ }^{6}$ STD NMR consists of applying a selective radio frequency pulse to a macromolecule at a resonance where no ligand signals are present. The magnetization is transferred to the bound ligands by spin-diffusion. ${ }^{7}$ Moreover, STD NMR allows the combination with almost any type of NMR experiment enabling a variety of investigations.

In this short report, an investigation was carried out to evaluate whether amide-lipase complexes could be detected by NMR via the monitoring of changes in the STD experiment and relaxation behavior ${ }^{8}$ for design the enzymatic kinetic resolution of organic amines by lipases (Scheme 1). The amines compounds have been chosen due to their great importance in biocatalysis ${ }^{9}$ and especially in the pharmaceutical industry since a huge number of molecule drug candidates have nitrogen atom. ${ }^{10}$ The chiral amines are also used as starting material to form new peptide bonds. ${ }^{11}$ Thus, the development of new procedures to understand and simplify biocatalysis methodologies to obtain chiral amines and/or amino acids is an area with great emphasis.

\section{Experimental}

The lipases (lipase Candida antarctica, CALB; Amano G, Amano M, lipase PS and Amano AK), (+)-methylbenzylamine (MBA), (-)-MBA, (+/-)-MBA and deuterated solvents (dimetil sulfoxide, DMSO- $d_{6}, 99.9 \%$ purity; deuterium oxide, $\mathrm{D}_{2} \mathrm{O}, 99.8 \%$ purity with $0.03 \% \mathrm{v} / \mathrm{v}$ 


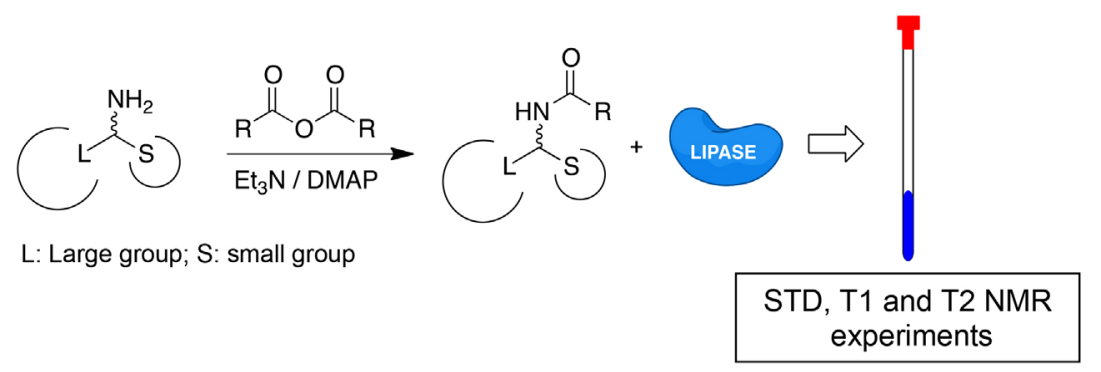

Scheme 1. Alternative design of lipases in the enzymatic kinetic resolution of amines.

of 3-(trimethylsilyl)propionic-2,2,3,3- $d_{4}$ acid sodium salt, TPS) were purchased from Sigma Aldrich ${ }^{\circledast}$ (St. Louis, MO, USA). The pronton $\left({ }^{1} \mathrm{H}\right)$ spectra were measured on a $300 \mathrm{MHz}$ Avance III Bruker (Billerica, MA, USA) equipped with a $5 \mathrm{~mm}$ direct broadband observed (BBO) probe. The chemical shifts of ${ }^{1} \mathrm{H}$ NMR are reported in parts per million $(\mathrm{ppm})$ relative to TPS peak ( $\delta 0.0 \mathrm{ppm})$, coupling constant $(J)$ in Hertz and integrated intensity.

The NMR samples were prepared in $\mathrm{D}_{2} \mathrm{O}$ :DMSO- $d_{6}$ (90:10) in a $1.0 \mathrm{mmol} \mathrm{L}^{-1}$ solution of chiral $\mathrm{N}$-(1phenylethyl)-acetamide with $0.4 \mathrm{mg}$ of lipase.

The acquisition of NMR spectra were recorded at a temperature of $298 \mathrm{~K}$ with a spectral width of $12 \mathrm{ppm}$. In STD experiment, selective saturation of the lipase was achieved by a train of Gaussian shaped pulse of $50 \mathrm{~ms}$ each, truncated at $1 \%$, and separated by a $1 \mathrm{~ms}$ delay. The duration of presaturation was $1.5 \mathrm{~s}$. A $\mathrm{T}_{1} \rho$ filter, $30 \mathrm{~ms}$ spin lock pulse was utilized to remove residual lipase resonances. The irradiation power of the selective pulse was $\gamma / \mathrm{B}_{1}=52 \mathrm{~Hz}$. The on-resonance irradiation $\left(\mathrm{I}_{\mathrm{on}}\right)$ of the lipase was performed at a chemical shift of $3.4 \mathrm{ppm}$. Off-resonance irradiation $\left(\mathrm{I}_{\text {off }}\right)$ was set at $40 \mathrm{ppm}$, where no lipase signals are present. A total number of 32 scans was collected for each experiment. Spectra processing was performed on a Bruker's TopSpin 3.2 software (Billerica, MA, USA).

\section{Results and Discussion}

The presented application of STD NMR allows to investigate the lipase-product binding directly from a lipase-containing product solution, when the hydrolysis rate constant of amide in aqueous solution is negligible. ${ }^{12}$ The use of racemic amine to straight measure the interaction with lipases was discarded because of the weak interaction observed in the NMR experiments. DMSO- $d_{6}$ solvent was added to solubilize the amide. The presence of $10 \%$ of DMSO- $d_{6}$ in the aqueous solution does not affect the catalytic activity and the solubility of all lipases evaluated. ${ }^{12}$ Initially, this issue was addressed by analysing model system, amide- $(R)$ and amide- $(S)$ with CALB to observe the chiral interaction effects and to optimize the STD NMR parameters. CALB lipase was used in the free form and was chosen to start the experiments due to the recognized structural stability, solvent tolerance, comercial availability, broad substrate scope and good catalytic activity in a enzymatic kinetic resolution reactions..$^{9,13,14}$ Relaxation experiments $\left(T_{1}\right.$ and $\left.T_{2}\right)$ were performed to corroborate the results of STD NMR.

Figure 1 shows the different steps involved in the STD NMR experiment, the ${ }^{1} \mathrm{H}$ spectrum of amide- $(R)$ and STD spectra of amide- $(R)$ in presence and without CALB lipase. The STD NMR experiment shows magnetization transferation to the amide- $(R)$ ligand only when the CALB is presented (Figure 1, spectrum b). The STD NMR experiment carried out with amide- $(S)$ and CALB in aqueous solution obtaining no signals. This evaluation is important to confirm that the transferation of NMR irradiation to ligand comes from lipase and do not from NMR experiment (Figure 1, spectrum c). The result obtained highlights the great stereospecificity of the proteins. Moreover, this simple method can be used to know which enantiomer will be formed without extensive use of high-performance liquid chromatography (HPLC) for new enzymes.

The selective saturation was optimized between -1.0-1.0 ppm and 3.0-4.0 ppm (Figure 1, NMR irradiation). Normally, it is not possible to irradiate peptides protons of the enzyme because of the presence of substrate signals, but in this situation there are not substrate signals, achieving a greater response saturating the CALB signal at $3.4 \mathrm{ppm}$. After these results, the inhibitory effect of amide- $(R)$ (enzymatic reaction product) was confirmed by STD NMR in which enzymatic kinetic resolution of amines ${ }^{13}$ do not have the same effectiveness than alcohols ${ }^{15}$ because of the strong interaction to lipase.

In the second set of experiment, the evaluation of differents lipases with racemic amide was performed. Usually, the design of lipase type on enzymatic kinetic resolution spend days or weeks. Computational studies ${ }^{16}$ and experimental procedures ${ }^{17}$ have been developed to aid this stage of planning. The focus is the simplification of biocatalysis design by NMR, significantly reducing 


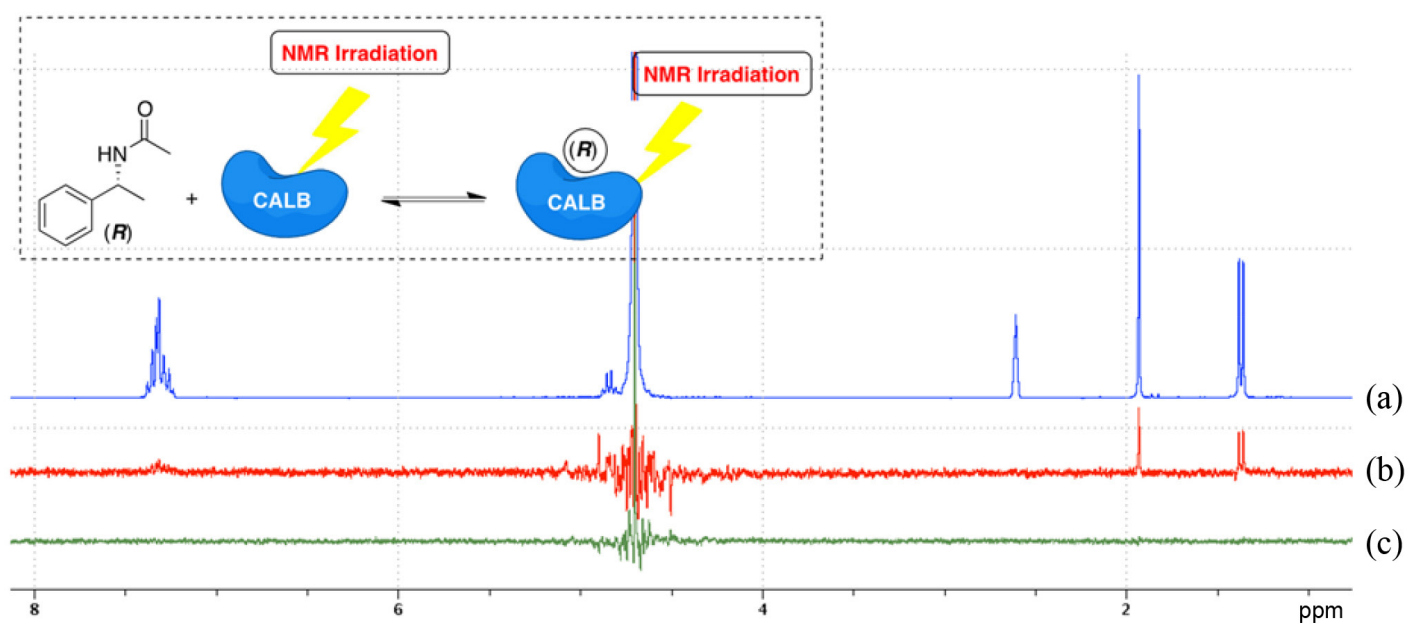

Figure 1. Amide- $(R)$ and lipase Candida antarctica (CALB) interaction in $\mathrm{D}_{2} \mathrm{O}: \mathrm{DMSO}-\mathrm{d}_{6}(9: 1)$ at $298 \mathrm{~K}$ by saturation transfer difference nuclear magnetic resonance (STD NMR) experiment. (a) ${ }^{1} \mathrm{H}$ NMR spectrum of amide- $(R)$; (b) STD NMR spectrum of amide- $(R)$ in presence of CALB lipase; and (c) STD NMR spectrum of amide- $(R)$ without CALB lipase.

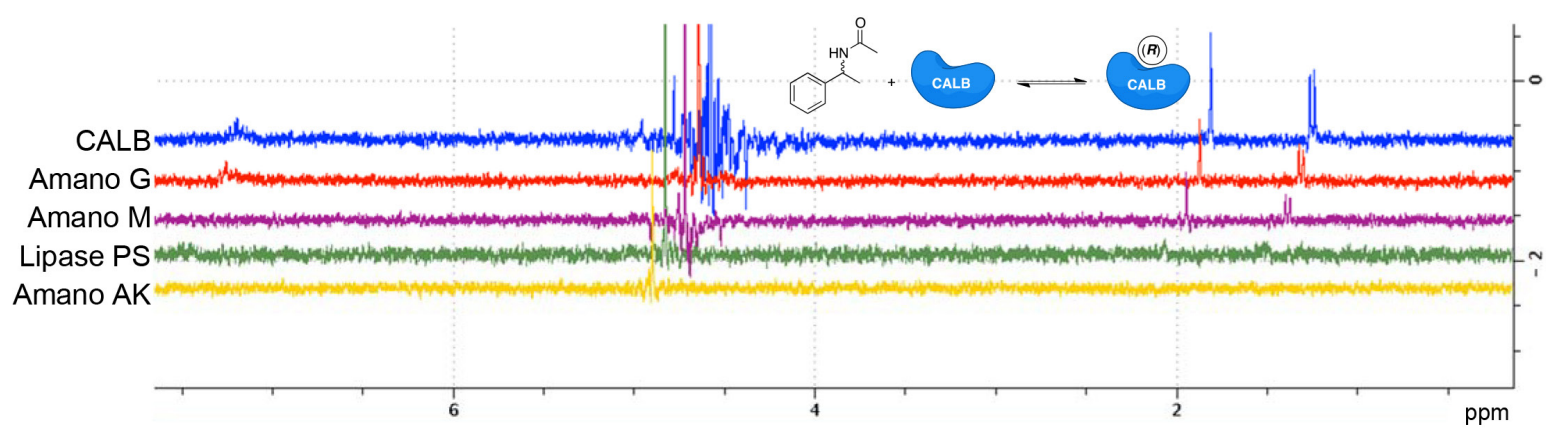

Figure 2. Racemic amide and lipases interaction in $\mathrm{D}_{2} \mathrm{O}: \mathrm{DMSO}_{6} \mathrm{~d}_{6}(9: 1)$ at $298 \mathrm{~K}$ by saturation transfer difference nuclear magnetic resonance (STD NMR) experiment. CALB: Lipase Candida antarctica.

the time-consuming of this step, employing the desired racemic amide. It is important to realize that the signals observed in the racemic amide-lipase interaction come only from the amide- $(R)$ as evaluated previously. This strategy was successfully employed by Thompson et al. ${ }^{18}$ in a simplification of chiral chromatographic development measuring the interaction of small substrates with stationary phases by STD NMR.

Results for lipases design in the enzymatic kinetic reaction of racemic amines by STD NMR experiments are shown in Figure 2. These data are promising evidence that the interaction between amide and lipase can be used as screening methodology in few minutes. Accordingly, lipases with strong STD effect of most protons indicating a spatial closeness with racemic amide and have a greater potential of carring out a effective biocatalysis (Figure 3, CALB, Amano G and Amano M), and lipases with weak or without STD effect could be discarded in the reaction steps (Figure 3, lipase PS and Amano AK). ${ }^{13}$ The STD effect can be improved replacing the acetyl group for trifluoroacetyl group (Figure 3). The carbon of carbonyl group becomes poorer in electrons, increasing the interaction with the lipase CALB. This effect can be visualized by the aromatic signals in the STD NMR experiment (Figure 3, spectrum b).

An important note is that the overall rate and selectivity of the enzymatic reaction depends on the protein environment. Lipases are highly sensitive to changes performed in the reaction medium, ${ }^{19}$ which STD NMR could be used to evaluate such as co-solvent, $\mathrm{pH}$ and temperature.

Although the binding strength is not directly proportional to the STD NMR effects, the results obtained were used as an exploratory exercise of adapting a protein-ligand interaction methodology for enzymatic kinetic resolution of amines. The present study also empirically optimized the STD parameters, including saturation transfer time, pulse width and pulse shape. Subsequently, the STD NMR measurements were compared to the results obtained from relaxation experiments.

Experiments based on relaxation is an important tool for studying the dynamics of free small molecules, such as ligands, inhibitors or substrates, and their macromolecular partners (protein, DNA and micelle). ${ }^{20}$ These experiments can be used to study the strength and topology of intermolecular interactions (Table 1). 


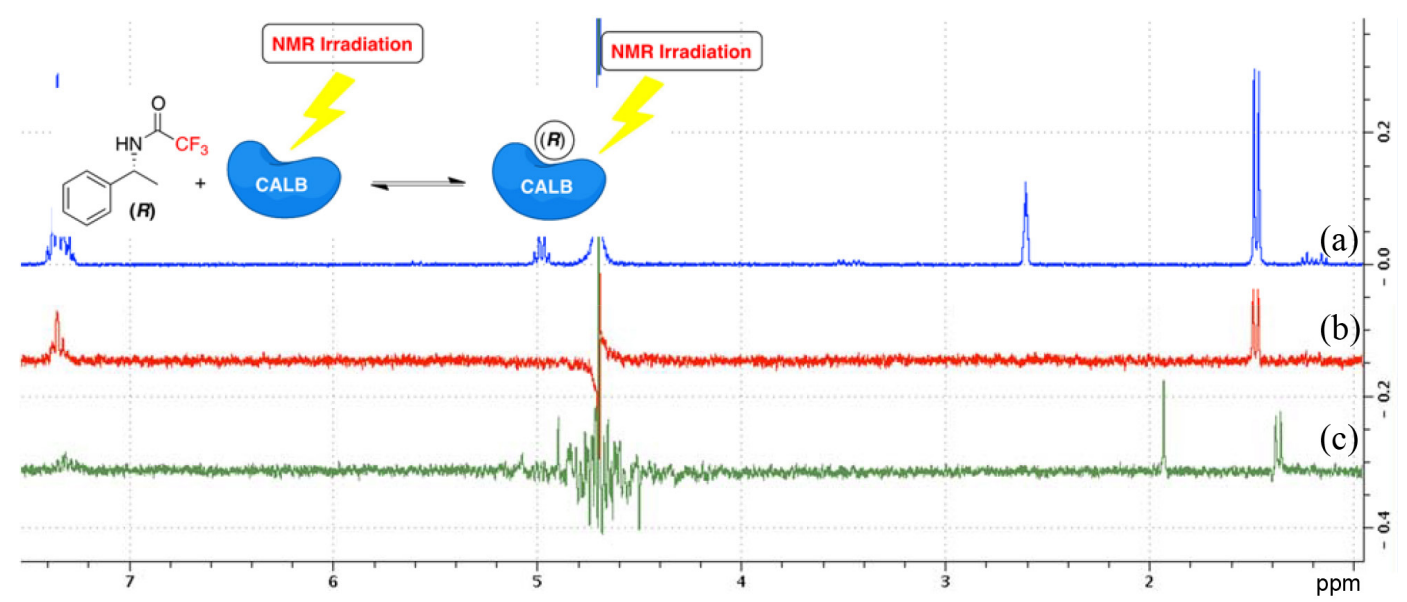

Figure 3. Amide- $\mathrm{CF}_{3}-(R)$ and lipase Candida antarctica (CALB) interaction in $\mathrm{D}_{2} \mathrm{O}: \mathrm{DMSO}-\mathrm{d}_{6}(9: 1)$ at $298 \mathrm{~K}$ by saturation transfer difference nuclear magnetic resonance (STD NMR) experiment. (a) ${ }^{1} \mathrm{H}$ NMR spectrum of amide- $\mathrm{CF}_{3}-(R)$; (b) STD NMR spectrum of amide-CF ${ }_{3}-(R)$ in presence of $\mathrm{CALB}$ lipase; and (c) STD NMR spectrum of amide- $(R)$ in presence of CALB lipase.

Table 1. Proton $\left({ }^{1} \mathrm{H}\right)$ nuclear magnetic resonance (NMR) relaxation experiments for interaction of racemic amide and lipases

\begin{tabular}{|c|c|c|c|c|c|c|}
\hline \multirow[b]{2}{*}{ entry } & \multirow[b]{2}{*}{ Lipase } & \multicolumn{3}{|c|}{${ }^{1} \mathrm{H}$ NMR signals observed in the relaxation experiments } & \multirow[b]{2}{*}{ Signal 3} & \multirow[b]{2}{*}{ Signal $4^{\mathrm{b}}$} \\
\hline & & Relaxation $^{\mathrm{a}}$ & Signal 1 & Signal 2 & & \\
\hline 1 & amide- $(R)$ & $\mathrm{T}_{1} / \mathrm{s}$ & 2.52 & 1.54 & 1.22 & 0.44 \\
\hline 2 & $(R)+\mathrm{CALB}$ & & 2.50 & 1.35 & 1.11 & 0.43 \\
\hline 3 & $(R)+$ Amano $\mathrm{G}$ & & 2.52 & 1.43 & 1.16 & 0.44 \\
\hline 4 & $(R)+$ Amano $\mathrm{M}$ & & 2.20 & 1.46 & 1.07 & 0.44 \\
\hline 5 & $(R)+$ lipase PS & & 1.83 & 1.51 & 1.07 & 0.44 \\
\hline 6 & $(R)+$ Amano $\mathrm{AK}$ & & 1.58 & 1.50 & 1.05 & 0.41 \\
\hline 7 & amide- $(R)$ & $\mathrm{T}_{2} / \mathrm{ms}$ & 500 & 120 & 1210 & 120 \\
\hline 8 & $(R)+\mathrm{CALB}$ & & 496 & 85 & 1072 & 117 \\
\hline 9 & $(R)+$ Amano $\mathrm{G}$ & & 500 & 102 & 1155 & 120 \\
\hline 10 & $(R)+$ Amano $\mathrm{M}$ & & 412 & 118 & 976 & 118 \\
\hline 11 & $(R)+$ lipase PS & & 450 & 114 & 994 & 120 \\
\hline 12 & $(R)+$ Amano $\mathrm{AK}$ & & 397 & 120 & 1113 & 115 \\
\hline
\end{tabular}

${ }^{\mathrm{a} A l l}$ relaxation experiments were performed in triplicate; ${ }^{\mathrm{b}}$ all aromatic signals. CALB: Lipase Candida antarctica.

A comparative study with the relaxation times of amide- $(R)$ and amide-lipase complexes was performed. Lower the relaxation time value reveals a strong interaction with lipase in the hydrogen position. Studies performed through relaxation experiments showed a strong interaction in the chiral center of amide (Table 1, entries 2-4 and 8-9) emphasizing the stereochemistry effect. These binding patterns resemble that groups linked to the aromatic fragment slightly changes the performance of enzymatic kinetic resolution. ${ }^{9,13-15}$ The lipase PS and Amano AK relaxation behaviors are enterily different from those signals (Table 1, entries 5, 6,11 and 12), suggesting altered binding. The relaxation experiments presented exhibit the same behavior as the STD NMR for lipases design. Based on the identification of small molecules binding to the lipase by STD NMR, new candidate amines compounds can be rated with CALB in aqueous solution $\left(\mathrm{D}_{2} \mathrm{O} / \mathrm{DMSO}-d_{6}\right.$, 90:10).

\section{Conclusions}

The application of STD NMR provides useful tool into the simplification of enzymatic kinetic resolution of amines design. The STD NMR method is rapid, simple and can be used to design a variety of lipases before the reaction steps, reducing drastically the time-consuming. The data from 
STD NMR and relaxation experiments provide insights for structural information that can be used to investigate the modes of interactions.

\section{Acknowledgments}

The authors thank the FAPESP 2014/23362-8 project for financial support.

\section{References}

1. Lin, G.-Q.; Li, Y.-M.; Chan, A. S. C.; Principles and Applications of Asymmetric Synthesis; John Wiley \& Sons: Oxford, 2001; Blaser, H.-U.; Schmidt, E.; Asymmetric Catalysis on Industrial Scale: Challenges, Approaches and Solutions; Wiley-VCG Verlag GmbH \& Co KgaA: Weinheim, 2004.

2. Sheldon, R. A.; Chiratecnology: Industrial Synthesis of Optically Active Coumponds; CRC Press: Boca Raton, 1993.

3. Thayer, A.; Chem. Eng. News 2008, 86, 12; Thayer, A.; Chem. Eng. News 2005, 83, 49; Tao, J.; Lin, G.; Liese, A.; Biocatalysis for the Pharmaceutical Industry: Discovery, Development and Manufacturing; John Wiley \& Sons: Oxford, 2009; Braga, A. L.; Schneider, P. H.; Lüdke, D. S.; Andrade, L. H.; Paixão, M. W.; Quim. Nova 2013, 36, 1591.

4. Aehle, W.; Enzymes in Industry: Production and Applications, Wiley-VCG Verlag GmbH \& Co KgaA: Weinhein, Germany, 2007; Bommarius, A. S.; Riebel, B. R. Biocatalysis, Wiley-VCG Verlag GmbH \& Co KgaA: Weinheim, 2004; Reetz, M.; J. Am. Chem. Soc. 2013, 135, 12480; Marsaioli, A. J.; Gonçalves, C. C. S.; Quim. Nova 2013, 36, 1587.

5. Hackl, T.; Meyer, B.; Exnowitz, F.; Biochim. Biophys. Acta 2012, 1824, 443; Peng, J. W.; Moore, J.; Manan, N. A.; Prog. Nucl. Magn. Reson. Spectrosc. 2004, 44, 225; Stockman, B. J.; Dalvit, C.; Prog. Nucl. Magn. Reson. Spectrosc. 2002, 41, 187; Krimm, I.; Guillière, F.; Cala, O.; Anal. Bioanal. Chem. 2014, 406, 943; Tashiro, M.; Furihata, K.; Shimotakahara, S.; Magn. Reson. Chem. 2005, 43, 69; Meyer, B.; Peters, T.; Angew. Chem., Int. Ed. 2003, 42, 864; Homans, S. W.; Angew. Chem., Int. Ed. 2004, 43, 290; Figueroa-Villar, J. D.; Soares, S. F. C. X. S.; Vieira, A. A.; Delfino, R. T.; Bioorg. Med. Chem. 2013, 21, 5923.

6. Cabeça, L. F.; Fernandes, S. A.; Paula, E.; Marsaioli, A. J.; Magn. Reson. Chem. 2008, 46, 838; Meyer, M.; Meyer, B.; Angew. Chem., Int. Ed. 1999, 38, 1784; Meyer, M.; Meyer, B.; J. Am. Chem. Soc. 2001, 123, 6108; Meyer, M.; James, T. L.; J. Am. Chem. Soc. 2002, 124, 13376; Krishnan, V. V.; Curr. Anal. Chem. 2005, 1, 307; Brecker, L.; Straganz, G. D.; Tyl, C. A.; Steiner, W.; Nidetzky, B.; J. Mol. Catal. B: Enzym. 2006, 42, 85; Peters, T.; Hinderlich, S.; Reutter, W.; Schmidt, R. R.; Blume, A.; Benie, A. J.; J. Biol. Chem. 2004, 279, 55722; Milagre, C.
D. F.; Cabeça, L. F.; Almeida, W. P.; Marsaioli, A. J.; J. Braz. Chem. Soc. 2012, 23, 403.

7. Marsaioli, A. J.; Figueiredo, I. M.; Quim. Nova 2007, 30, 1597.

8. Figueroa-Villar, J. D.; Tinoco, L. W.; Curr. Top. Med. Chem. (Sharjah, United Arab Emirates) 2009, 9, 811.

9. Gotor, V.; Busto, E.; Gotor-Fernández, V.; Adv. Synth. Catal. 2006, 348, 797.

10. Carey, J. S.; Laffan, D.; Thomson, C.; Williams, M. T.; Org. Biomol. Chem. 2006, 4, 2337; Gotor, V.; Cerrada, S. G.; Mendiola, J.; Frutos, O.; Collado, I.; Fernández, V. G.; Lavandera, I.; Busto, E.; Mata, M. R.; Paul, C. E.; Org. Process Res. Dev. 2014, 16, 788.

11. Bhattacharya, A.; Bandichhor, R. In Green Chemistry in the Pharmaceutical Industry; Dunn, P. J.; Wells, A. S.; Williams, M. T., eds.; Wiley-VCG Verlag GmbH \& Co KgaA: Weinhein, 2010, ch. 14; Nestl, B. M.; Hammer, S. C.; Nebel, B. A.; Hauer, B.; Angew. Chem., Int. Ed. 2014, 53, 3070.

12. Faber, K.; Biotransformations in Organic Chemistry, $5^{\text {th }}$ ed.; Springer-Verlag: Berlin, 2004.

13. Andrade, L. H.; Silva, A. V.; Tetrahedron: Asymmetry 2008 , 19, 1175; Andrade, L. H.; Barcellos, T.; Santiago, C. G.; Tetrahedron: Asymmetry 2010, 21, 2419.

14. Kanerva, L. T.; Perkiö, P.; Päiviö, M.; Tetrahedron: Asymmetry 2012, 23, 230; Pilissão, C.; Carvalho, P. O.; Nascimento, M. G.; Process Biochemistry (Oxford, U. K.) 2009, 44, 1352; Yadav, G. D.; Sontakke, J. B.; J. Chem. Technol. Biotechnol. 2011, 86, 739; Vongvilai, P.; Ramström, O.; J. Am. Chem. Soc. 2009, 131, 14419; Gotor, V.; Gotor-Fernández, V.; Busto, E.; Torre, O.; Adv. Synth. Catal. 2007, 349, 481; Pilissão, C.; Carvalho, P. O.; Nascimento, M. G.; J. Braz. Chem. Soc. 2010, 21, 973.

15. Raminelli, C.; Comasseto, J. V.; Andrade, L. H.; Porto, A. L. M.; Tetrahedron: Asymmetry 2004, 15, 3117; Porto, A. L. M.; dos Santos, A. A.; Wendler, E. P.; Melgar, G. Z.; Tetrahedron: Asymmetry 2010, 21, 2271; Porto, A. L. M.; Andrade, L. H.; Teixeira, C. C.; Bianco, G. G.; Ferraz, H. M. C.; Tetrahedron: Asymmetry 2007, 18, 1070; Andrade, L. H.; Barcellos, T.; Org. Lett. 2009, 14, 3052.

16. Graber, M.; Tran, V.; Domon, L.; Pineau, P.; Marton, Z.; Chaput, L.; J. Mol. Catal. B: Enzym. 2012, 84, 55; Graber, M.; Tran, V.; Chaput, L.; J. Mol. Catal. B: Enzym. 2012, 76, 29; Lee, H.; Park, S.; Kim, B. T.; Min, B.; Park, A.-R.; Jeon, N. Y.; Lim, J. Y.; Adv. Synth. Catal. 2013, 355, 1808.

17. Kim, M.; Choi, Y. K.; Lee, D.; Org. Lett. 2000, 2, 2553; Graber, M.; Leonard, V.; Marton, Z.; Cusatis, C.; Lamare, S.; J. Mol. Catal. B: Enzym. 2008, 52, 121; Fernández-Lafuente, R.; Guisán, J. M.; Fernández-Lafuente, G.; Palomo, J. M.; Adv. Synth. Catal. 2007, 349, 1119; Parve, O.; Reile, I.; Parve, J.; Kasvandik, S.; Kudrjasova, M.; Tamp, S.; Metsala, A.; Villo, L.; Pehk, T.; Jurvet, J.; Vares, L.; J. Org. Chem. 2013, 78, 12795.

18. Thompson, M. R.; McKenzie, D. R.; Likos, J. J.; Gard, J. K.; Magn. Reson. Chem. 2009, 47, 541. 
19. Tao, J.; Gujral, A.; Deese, A.; Panesar, M.; Derrick, A.; Yazbeck, D.; Org. Process Res. Dev. 2006, 10, 655; Bélafi-Bakó, K.; Szabó, L.; Dombi, A.; Nagy, E.; J. Mol. Catal. B: Enzym. 1994, 94, 291.

20. LaPlante, S. R.; Aubry, N.; Déziel, R.; Ni, F.; Xu, P.; J. Am. Chem. Soc. 2000, 122, 12530; Shajani, Z.; Varani, G.; J. Mol. Biol. 2005, 349, 699; Peng, J. W.; J. Am. Chem. Soc. 2003, 125,
4929; Mikhailov, D.; Mayo, K. H.; Pervin, A.; Linhardt, R. J.; Biochem. J. 1996, 315, 447.

Submitted: January 16, 2016 Published online: March 15, 2016

FAPESP has sponsored the publication of this article. 